\title{
Closure of astrophysics laboratory blamed on Enola Gay 'fallout'
}

Washington. The US National Air and Space Museum in Washington, DC, is to close its Laboratory of Astrophysics, angering astrophysicists who point to the laboratory's strong track record in research and teaching.

The closure of the laboratory is being widely viewed as retribution against Martin Harwit, an astrophysicist and former director of the museum, who founded the small laboratory in 1987. Harwit was forced to resign last year after veterans' organizations and congressmen objected to plans for an exhibition about Enola Gay, the aircraft that dropped the first atomic bomb (see Nature 375, 95; 1995).

The Smithsonian board of regents asked for a review of the laboratory last year, after critics had asserted - falsely - that its main function had been to support Harwit's own research. An external panel, chaired by Maxine Singer, head of the Carnegie Institution, rebutted criticism of the laboratory. But Don Engen, the museum's new director, told staff last month that the laboratory will close by the end of this year.

With a core staff of only three, whose salaries have been paid by the Smithsonian, the laboratory had attracted $\$ 4$ million in external research grants since its inception. Its researchers have published 150 papers, conducting top quality research in a range of special topics, including optics for hightransmission infrared spacecraft systems, and spectroscopy for velocity-resolved studies of planetary atmospheres.

Perhaps the laboratory's most important function, however, has been to provide the museum with scientific advice on its exhibits, and to help with its external education efforts, including the widely circulated IMAX movies Cosmic Voyage and Destiny in Space.

Howard Smith, the head of the laboratory, declines to comment on the circumstances surrounding the planned closure. But colleagues of staff members point out that the closure will not save the Smithsonian any money, as external grants cover its operating costs. "This has to do with the Enola Gay exhibition and Martin Harwit's resignation, and [the Smithsonian] wanting to make a clean sweep of things that Harwit created," one said.

Engen was unavailable for comment. But his deputy, Don Lopez, says the laboratory is closing because it is "not right in our primary core function" of putting on displays, which Congress told the museum to concentrate on. Lopez says that the museum has already reduced its staff from 235 to 213 following budget cuts, and has been instructed to reduce the number to 201 by

\section{Governor blocks genetic property right}

Washington. The Republican governor of New Jersey - home to dozens of biotechnology companies, and more major US pharmaceutical companies than any other state - has vetoed a bill creating a property right to genetic information, warning that it could "chill" research in the state.

The Genetic Privacy Bill had earlier been unanimously approved by the state legislature. Governor Christine Todd Whitman issued a conditional veto of the bill last month, arguing that its creation of a property right was "not needed" to protect privacy.

Those pushing for the veto included the Biotechnology Industry Organization, whose president, Carl Feldbaum, called the bill "so badly written" that it would have eliminated much basic research, including many clinical trials.

The 'conditional' veto means that, if the changes suggested by Whitman are incorporated, the bill can be passed into law by a simple majority, rather than the two-thirds normally needed to override a veto. Whitman has asked for the property right provision to be dropped, and those primarily responsible for drafting the bill say they will remove it.

"The most important issue is to protect New Jersey residents from genetic discrimination. Therefore it's most appropriate to move the bill forward," says Steven Andreassen, a legislative aide to Jack Sinagra (Republican), a key Senate backer of the original bill. But he says that Sinagra still opposes in principle the removal of the property rights provision.

The bill was approved by the New Jersey Senate by 38 votes to nil in June, and passed unanimously by the Assembly the same month. The pharmaceutical

Meredith Wadman industry is the state's largest high technology employer.

\section{IMAGE \\ UNAVAILABLE \\ FOR COPYRIGHT REASONS}

Seeing red: staff use a laser to develop optics for infrared spacecraft systems.

the end of next year.

Lopez denies that the laboratory is being closed because it was Harwit's creation: "Harwit is already gone - how could it be retribution against him?" The museum will retain its other, larger laboratory, the Center for Earth and Planetary Studies, whose staff are mainly geologists. Lopez says that laboratory is being retained because it "provides a unique function" and has existed "ever since the museum was founded" in 1976.

Harwit says that the closure of the astrophysics laboratory is "a step backwards" that could have been avoided within the staff reductions that the museum is making. "I set up the laboratory because I felt that an essential part of telling the story of space required people who were actively involved in space science," he says. The museum's exhibits and education programmes "need that kind of expertise. You can't do that if you just have people who read about it in the Encyclopaedia Britannica".

A proposal to integrate some of the laboratory's activities into the Smithsonian Astrophysical Laboratory in Cambridge, Massachusetts, directed by Irwin Shapiro, was rejected last week by the Smithsonian management. Lopez says that the museum will be able to call on the Cambridge laboratory for scientific advice as required. Two of the astrophysics laboratory's three permanent staff have now found jobs elsewhere.

Colin Macilwain 